\title{
PASS-predicted Vitex negundo activity: antioxidant and antiproliferative properties on human hepatoma cells-an in vitro study
}

Farkaad A Kadir ${ }^{1 \dagger}$, Normadiah M Kassim ${ }^{1 *}$, Mahmood A Abdulla ${ }^{2 \dagger}$ and Wageeh A Yehye ${ }^{3 \dagger}$

\begin{abstract}
Background: Hepatocellular carcinoma is a common type of tumour worldwide with a high mortality rate and with low response to current cytotoxic and chemotherapeutic drugs. The prediction of activity spectra for the substances (PASS) software, which predicted that more than 300 pharmacological effects, biological and biochemical mechanisms based on the structural formula of the substance was efficiently used in this study to reveal new multitalented actions for Vitex negundo (VN) constituents.
\end{abstract}

Methods: Experimental studies based on antioxidant and antiproliferative assays verified the predictions obtained by the PASS-predicted design strategy. Antioxidant activity of VN extract was studied using 1,1-diphenyl-2-picrylhydrazyl (DPPH) and Ferric reducing or antioxidant power (FRAP) assays. The antiproliferative activity of VN extract against WRL68 and HepG2 was investigated based on methylthiazol tetrazolium (MTT) spectrophotometric assay.

Results: VN extract showed $79.43 \%$ inhibition of DPPH stable radical with $I_{50} 13.31 \pm 0.18 \mu \mathrm{g} / \mathrm{ml}$. This inhibition was too closed to butylated hydroxyl toluene (BHT) 82.53\% (IC $\mathrm{C}_{50} 13.8 \pm 0.14$ ) and gallic acid $89.51 \%\left(\mathrm{IC}_{50} 3.1 \pm 0.08\right)$. VN extract exhibited the strongest free radical scavenging power compared with two commercial antioxidants, BHT and ascorbic acid. VN increased the activities of antioxidant enzymes in normal embryonic liver cells (WRL68) including, superoxide dismutase (SOD) and glutathione peroxidase (GPX) compared with to $\mathrm{H}_{2} \mathrm{O}_{2}$ group. The ethanolic extract of VN showed cytotoxicity to HepG2 cells in a dose and time-dependent manner with $\mathrm{IC}_{50}$ $66.46 \mu \mathrm{g} / \mathrm{ml}, 57.36 \mu \mathrm{g} / \mathrm{ml}$ and $65.12 \mu \mathrm{g} / \mathrm{ml}$ at 24, 48, and 72-hours incubation respectively, with no sensitivity in WRL68 cells. This was associated with significant elevation in lactate dehydrogenase (LDH) release in HepG2 cells. In addition, the activation of caspase-3 enzyme suggesting that the observed cytotoxicity was mediated via an intrinsic apoptosis pathway.

Conclusions: PASS-predicted plant activity could efficiently help in selecting a promising pharmaceutical leads with high accuracy and required antioxidant and antiproliferative properties. This is the first report on PASS-predicted VN activity.

Keywords: Antioxidant, Caspase 3, HepG2, LDH, MTT, PASS, Vitex negundo, WRL68

\footnotetext{
*Correspondence: normadiah_mk@um.edu.my

${ }^{\dagger}$ Equal contributors

'Department of Anatomy, Faculty of Medicine, University of Malaya, 50603,

Kuala Lumpur, Malaysia

Full list of author information is available at the end of the article
} 


\section{Background}

Hepatocellular carcinoma (HCC) is a frequent tumour worldwide. It approximately accounts for $6 \%$ of cancer occurrences among human and overall, it rates as the seventh most common malignancy in males and the ninth most in females [1]. At least, one million new cases of HCC occur annually and mortality of the disease remains high despite the treatment especially in Southeast Asia countries and tropical Africa, which show the highest incidence [2]. Substantial advances have been applied in the chemotherapy regimen for treating patients with HCC; however, still there is an urge to discover and explore effective strategies for its treatment throughout the use of medicinal plants. Some of the most effective cancer treatments to date are natural products or compounds derived from natural products [3]. Therefore, it is common that there was increasing to find the biological activity among plants with approved medicinal uses rather than from plants randomly selected.

Due to absence of an effective chemotherapy for liver cancer, many studies using different cell lines, animal models and human epidemiological trials have been shown to have considerable potential of herbal medicine to act as anti-proliferative agents and have received a special attention lately [4]. To date, there have been several large (at least 7000 participants) trials testing the efficacy of antioxidant supplements in preventing cancer. A recent review of available literature suggests antioxidants function to prevent free radical damage, and that's important in preventing our bodies from cancers, arthritis, diabetes, autoimmune diseases and $90+$ other diseases [5]. The antioxidant activity of phenolics is mainly due to their redox properties, which allow them to act as reducing agents, hydrogen donors, singlet oxygen quenchers and metal chelators. Meanwhile, the strategy for research and in vitro evaluation of biological activity of natural products has changed in the past few years.

$\mathrm{VN}$ is a perfect example of medicinal plant credited by numerous medicinal qualities validated by modern science and used since ancient times. It belongs to the family of Verbenceae, and the genus consists of 250 species and most of them have commercial and medicinal importance [6]. It is a large aromatic shrub and commonly called five leaved chaste tree or Monk's Pepper [7]. The leaves contain an alkaloid, flavonoids like flavones, luteolin7-glucoside, casticin, iridoid, glycosides, an essential oil and other constituents like vitamin $C$, carotene, glucononital, benzoic acid, $\beta$-sitosterol and glycoside [6]. The plant has a pungent, bitter, acrid taste used in various traditional treatment of stomach-ache, disease of the eye, inflammation, enlargement of spleen, bronchitis, asthma, as an antihelmintic, to promote growth of hair and painful teething in children [8].
The isolated compound from the $\mathrm{VN}$ extract showed protection of hepatocytes, nephrocytes and pancreatic $\beta$ cells probably by its action against NF-kB and inducednitric oxide synthase iNOS mediated inflammation in streptozotocin-induced diabetes [9]. VN seeds extract showed analgesic, antinociceptive activity [10] and hepatoprotective activity [11-13].

Apoptosis is a type of programmed cell death; it allows proper development and remodeling of normal tissues, besides generating immune responses and destroying abnormal cells. It is well known that malignant transformation of human cancer cells is a multi-staged process involving mutation or deletions of various human suppressor's genes. This can lead to activation of oncogenes and alterations in the level of expression of key regulatory genes, providing growth advantages and metastatic potential for tumor cells [14]. Those genetic alterations result in abnormalities in cellular and nuclear morphology and signal transduction pathways. This would normally activate a suicidal pathway and induce apoptosis in the cells leading to defects and/or mutations of p53 delay cell-cycle arrest and abolish the DNA repair process, which otherwise render the cells to apoptosis [2]. Virtual screening is of specific significance to understand the pharmacological action of the plant compounds [15]. The prediction of activity spectra for substances (PASS) software [16], predicted more than 300 pharmacological effects, biological and biochemical mechanisms based on the structural formula of the substance. This was efficiently used in this study to reveal new multitalented actions for the isolated components of $\mathrm{VN}$ extract.

HepG2 cell line represents one of the most widely used experimental model for in vitro studies on HCC [17]. Hence, this work was carried out to investigate the antioxidant, antiproliferative and apoptotic effect of ethanolic extract of VN extract against WRL68 and HepG2 cell lines based primarily on the rich literature review with the support of PASS prediction program.

\section{Methods}

\section{Computational evaluation of biological activity}

The biological activity spectra of the phytoconstituents for VN extract were obtained using the Prediction of Activity Spectra for Substances (PASS) software. PASS prediction tool is constructed using 20,000 principal compounds from the MDDR database (produced by Accelrys and Prous Science) [18].

\section{Preparation of crude ethanol extract}

Fresh leaves of VN plant were obtained from Kampung Baru, Sungai Ara, Penang, Malaysia. The plant was identified and the voucher specimen number (KLU 34968) was deposited in University Malaya (Department of Pharmacy). Dried and ground leaves of $\mathrm{VN}$ were 
weighed, then homogenized in $95 \%$ ethanol at a ratio of $1: 10$ of plant to ethanol and left to soak for 4 days at $25^{\circ} \mathrm{C}$ while shaking and stirring it occasionally. The mixture was filtered, centrifuged at $14,000 \mathrm{rpm}$ for $10 \mathrm{~min}$ and then concentrated under reduced pressure at $45^{\circ} \mathrm{C}$ to obtain a dark gummy-green extract. The concentrated extracts were then frozen and finally lyophilized with freeze dryer, yielding the crude extract of the leaves of $\mathrm{VN}$.

\section{DPPH scavenging assay}

The extract was measured in terms of hydrogen donating or radical scavenging ability using the stable radical $\mathrm{DPPH}$ following the method described by Gorinstein et al., 2003 [19]. The colour change of the reaction mixture was then read at $517 \mathrm{~nm}$ against the blank, which did not contain the extract. Galic acid, ascorbic acid and BHT were used as a positive control. Samples without treatment were used as negative control. The percentage of DPPH decolourization of the sample was calculated as

$$
\begin{aligned}
& \text { DPPH scavenging effect }(\%) \\
& =(\text { Control A-Sample A/Control A }) \times 100
\end{aligned}
$$

Where Control A is the absorbance of the control reaction. Sample A is the absorbance in the presence of VN extract. The test was conducted in triplicate.

\section{FRAP Assay}

The FRAP assay measures the change in absorbance at $593 \mathrm{~nm}$ due to the formation of blue coloured $\mathrm{Fe}^{2+}-$ tripyridyltriazine (Fe - TPTZ) compound from the colourless oxidized $\mathrm{Fe}^{3+}$ form by the action of electron donating antioxidants [20]. The experiment was conducted at $37^{\circ} \mathrm{C}$ under $\mathrm{pH} 3.6$ condition with a blank sample in parallel. In the FRAP assay, reductants "antioxidants" in the sample reduce Fe (III)/tripyridyltriazine complex, present in stoichiometric excess, to the blue ferrous form, with an increase in absorbance at $593 \mathrm{~nm}$.

Briefly $50 \mu \mathrm{l}$ from the dissolved extract was added to $1.5 \mathrm{ml}$ freshly prepared and pre warmed $\left(37^{\circ} \mathrm{C}\right)$ FRAP reagent (300 mM acetate buffer, $\mathrm{pH}_{3} .6,10 \mathrm{mM}$ TPTZ in $40 \mathrm{mM} \mathrm{HCl}$ and $20 \mathrm{mM} \mathrm{FeCl} \cdot 6 \mathrm{H}_{2} \mathrm{O}$ in the ratio of 10 : 1:1) and incubated at $37^{\circ} \mathrm{C}$ for $10 \mathrm{~min}$. The absorbance of the sample was read against reagent blank $(1.5 \mathrm{ml}$ FRAP reagent $+50 \mu$ distilled water) at $593 \mathrm{~nm}$. Increased absorbance of the reaction mixture indicated increased reducing power. Ascorbic acid, galic acid and BHT were used as standards. All analyses were run in triplicate and results averaged.

\section{In vitro VN antioxidant inWRL68 cell lines}

The VN extract was used for in vitro antioxidant experiment. Approximately, $1000 \mu \mathrm{l}$ of the WRL-68 cell line suspension were seeded in 12-well flat bottom micro titer plates at $2 \times 10^{6}$ cells $/ \mathrm{ml}$ in Dulbecco's Modified Eagle Medium (DMEM ) containing 10\% (v/v) FBS and allowed to attach overnight. The second day, the cells were treated with $100 \mu \mathrm{g}$ of $\mathrm{VN}$ extract in triplicate according to Table 1 and incubated at $37^{\circ} \mathrm{C}$ with $5 \% \mathrm{CO}_{2}$ for 2 hours. The treated cells were induced by $100 \mu \mathrm{l}$ of freshly prepared $1000 \mu \mathrm{M} \mathrm{H} \mathrm{H}_{2} \mathrm{O}_{2}$ and re-incubated for 2 hours. The $\mathrm{H}_{2} \mathrm{O}_{2}$-treated and untreated cells after removing the medium, were harvested, washed twice with PBS and lysed in lysis buffer $(25 \mathrm{mmol} / \mathrm{l}$ Tris- $\mathrm{HCl})$. WRL-68 cell lysates were prepared in a $0.5 \mathrm{ml}$ cold phosphate buffer saline (PBS) (pH 7.4) [21]. All the cell debris was removed by centrifugation at $100 \mathrm{rpm}$ for $10 \mathrm{~min}$ at $4^{\circ} \mathrm{C}$ using refrigerated centrifuge Rotofix 32 (Hettich Zentrifugen, Germany). All samples were sonicated for $5 \mathrm{~min}$ with $10 \mathrm{sec}$ rest after each min. The samples were kept at $-20^{\circ} \mathrm{C}$ until used. The supernatant was used for the estimation of the following antioxidant using commercially available kits from (Cayman Chemical Company, USA): malondialdehyde (MDA) (Item No. 10009055), superoxide dismutase (Item No. 706002) and glutathione peroxidase (Item No. 703102) activities.

\section{Cell culture}

Two types of cells were used; (WRL68) and (HepG2). Both cell types were obtained from Department of Molecular Medicine, Faculty of Medicine, University of Malaya. Cells were cultured in the DMEM, supplemented with $10 \%$ fetal bovine serum, penicillin (100 units/ml-streptomycin $(100 \mu \mathrm{g} / \mathrm{ml})$, using $75 \mathrm{~cm}^{2}$ flasks in a $37^{\circ} \mathrm{C}$ in humidified $5 \% \mathrm{CO}_{2}$ incubator.

\section{MTT assay}

Briefly, the cells were plated into 96-well plates at the density of $1.5 \times 10^{4} /$ well in the final volume of $100 \mu \mathrm{l}$ culture medium per well. On the following day, the cells were treated with various concentration of VN plant extract at doses of $6.25,12.5,25,50,100$ and $200 \mu \mathrm{g} / \mathrm{ml}$ and maintained at $37^{\circ} \mathrm{C}$ with $5 \% \mathrm{CO}_{2}$ for 24,48 and 72 hours. Sample without treatment was used as negative control. At the end of the incubation period, $20 \mu \mathrm{L}$ of MTT reagent was added to each well and incubated again for 4 hours at $37^{\circ} \mathrm{C}$ with $5 \% \mathrm{CO}_{2}$, then $100 \mu \mathrm{L}$ of dimethylsulphoxide (DMSO) was added into each well and the absorbance was determined at $540 \mathrm{~nm}$ using ELISA reader. The cell viability percentage was calculated using the formula:

$$
\mathrm{A}_{550 \mathrm{~nm}}(\text { sample }) / \mathrm{A}_{550 \mathrm{~nm}}(\text { control }) \times 100
$$

Where A (sample) is the absorbance of wells containing different concentrations of plant extract and $\mathrm{A}$ 
Table 1 In vitro antioxidant for cell line experimental design

\begin{tabular}{|c|c|c|}
\hline Group Name & Oxidant agent $\left(1000 \mu \mathrm{M} \mathrm{H}_{2} \mathrm{O}_{2}\right)$ & Treatment $(100 \mu \mathrm{g} / \mathrm{ml})$ \\
\hline Normal (untreated cell group) & No oxidant agent ( $10 \mu$ l medium) & $10 \mu \mathrm{l}$ solvent \\
\hline $\mathrm{H}_{2} \mathrm{O}_{2}$ (Oxidative damaged group) & $10 \mu \mathrm{l}$ & $10 \mu \mathrm{l}$ solvent \\
\hline VN & $10 \mu \mathrm{l}$ & VN ethanol extract $(10 \mu \mathrm{l})$ \\
\hline
\end{tabular}

(control) is the absorbance of control wells containing cell culture medium without samples. The experiment was carried out in triplicates [22].

\section{Cell observation using an inverted microscope}

HepG2 cell lines were cultured in 96-well plates and treated with $\mathrm{VN}$ ethanolic extract. The cells were then rinsed with $1 \times$ Phosphate Buffer Saline (PBS) (Sigma). Morphological and confluence changes of the cells in VN-treated group $57.36 \mu \mathrm{g} / \mathrm{ml}$ according to $\mathrm{IC}_{50}$ and untreated group for 48 hours were observed under $\times 10$ magnification by a trinocular inverted phase contrast microscope (Olympus, Japan).

\section{Acridine orange/ethidium bromide (AO/EB) staining}

Dual staining with acridine orange and ethidium bromide was performed based on the protocol previously described [23]. Cells were seeded in six well plates for 48 hours and subjected to treatment with $\mathrm{VN}$ in a dose of $57.36 \mu \mathrm{g} / \mathrm{ml}$ according to $\mathrm{IC}_{50}$. After incubation, the cells were harvested by trypsinization and rainsed with PBS, and then stained with $0.1 \mathrm{mg} / \mathrm{ml}$ acridine orange and $0.1 \mathrm{mg} / \mathrm{ml}$ ethidium bromide. Stained cell suspension $(10 \mu \mathrm{l})$ was placed on a clean glass slide and covered with a cover slip. The cells were then observed under a fluorescence microscope (Leica) in both red channel $(590 \mathrm{~nm})$ and green channel $(520-550 \mathrm{~nm})$.

\section{Lactate dehydrogenase (LDH) assay}

To determine the effects of ethanolic extract of $\mathrm{VN}$ on membrane permeability in WRL 68 and HepG2 cell lines, LDH release assay was done using (Cayman Chemical Company, USA) LDH Cytotoxicity Assay Kit, (item No. 10008882). The presence of LDH enzyme in the cell culture medium is an indication of cell membrane damage [24]. Basically, LDH cytotoxicity assay kit measures cell death in response to chemical compounds using a coupled two-step reaction. In the first step, LDH catalyzes the reduction of $\mathrm{NAD}^{+}$to $\mathrm{NADH}$ and $\mathrm{H}^{+}$by oxidation of lactate to pyruvate. In the second step of the reaction, diphorase uses the newly-formed NADH and $\mathrm{H}^{+}$to catalyze the reduction of a tetrazolium salt (INT) to highly-coloured formazan which absorbs strongly at 490-520 $\mathrm{nm}$. The amount of formazan produced is propotional to the amount of LDH released into the culture medium as a result of cytotoxicity.
The cells were seeded in a 96-well plate at a density of $10^{4}-10^{5}$ cells/well in $120 \mu \mathrm{l}$ of culture medium with or without compounds to be tested.

\section{Detection of apoptosis of HepG2 cells by measuring caspase- 3 enzyme activity}

Caspase- 3 activity was assessed using the caspase3Colorimetric Assay Kit (BioVison), following the manufacturer's instructions is based on spectrophotometric detection of the chromophore $p$-nitroaniline $(p \mathrm{NA})$ after cleavage of a specific substrate DEVD-pNA.

The HepG2 cells were seeded in sterile $60 \mathrm{~mm}$ dishes, and at the end of $\mathrm{VN}$ treatment, the cells were washed with PBS and lysed in lysis buffer provided by the kit. After freezing and thawing three times, the cell lysate was centrifuged at $20,000 \times \mathrm{g}$ at $4^{\circ} \mathrm{C}$ for 15 minutes. The supernatants were collected and DEVD-pNA was then added and incubated for $1-2$ hours at $37^{\circ} \mathrm{C}$. The concentration of the pNA released was measured at $405 \mathrm{~nm}$, and the quantity of pNA was calculated from a calibration curve of pNA standard. Caspase- 3 activity was expressed spectrophotemetrically compared to the control untreated cells. The experiment was carried out in triplicates [25].

\section{Statistical analysis}

The analysis of variance (ANOVA) was used to determine differences between treated and control groups with $p<0.05$ being considered as statistically significant, using SPSS programme for Windows version 18.0 (SPSS Inc. Chicago, IL, USA).

\section{Results and discussion}

\section{PASS prediction and assistant experimental design}

In order to accelerate the research for potent natural products, computer-aided drug discovery program PASS was used to predict the antioxidant and antioproliferative properties. PASS prediction tools were constructed using 20000 principal compounds [26] and about 4000 kinds of biological activity on the basis of structural formula with mean accuracy about 90\% [27]. The result of prediction is presented as the list of activities with appropriate $\mathrm{Pa}$ and Pi ratio.

$\mathrm{Pa}$ and $\mathrm{Pi}$ are the estimates of probability for the compound to be active and inactive, respectively. It is reasonable that only those types of activities may be revealed by the compound, which $\mathrm{Pa}>\mathrm{Pi}$. If $\mathrm{Pa}>0.3$ the 
compound is likely to reveal this activity in experiments, but in this case the chance of being the analogue of the known pharmaceutical agents for this compound is also high. Thus, potential biological effects of the plant constituents were predicted by PASS program based on structure activity relationship (SAR) analysis of the training set containing thousands of compounds which have many kinds of biological activity. Therefore, before we started our experiments, we used PASS program to validate whether VN constituents based on SAR strategy is in agreement with the SAR of the training set of the PASS database.

A portion of the predicted biological activity spectra (lipid peroxidase inhibitor, antioxidant, free radical scavenger, hepatoprotectant, caspase-3 stimulant and antiproliferative) for the $\mathrm{VN}$ extract isolated compounds are given in Table 2.

\section{DPPH assay}

The DPPH assay was utilized to evaluate the ability of the investigated $\mathrm{VN}$ ethanolic extract to act as donors of hydrogen atoms or electrons in transformation of $\mathrm{DPPH}$ radical into its reduced form DPPH-H. The extract of $\mathrm{VN}$ was able to reduce the stable purple-coloured radical DPPH into the yellow-colored DPPH-H. The scavenging activities of $\mathrm{VN}$ extract, ascorbic acid, galic acid and BHT on DPPH radicals were compared as shown in Figure 1. Percentage of radical scavenging activity at the highest concentration was $79.43 \pm 1.3$ for $\mathrm{VN}, \mathrm{BHT}$ $82.53 \pm 1.7$, galic acid $89.51 \pm 1.14$ and ascorbic acid $90.65 \pm 1.34$.

Ferric Reducing antioxidant power (FRAP) of VN extract The reducing ability of the VN extract was in the range of $866.11 \mu \mathrm{mol} \mathrm{Fe}(\mathrm{II}) / \mathrm{g}$. The FRAP value for VN extract was lower than ascorbic acid and galic acid, but significantly higher than BHT (Figure 2).
The phenolic components most frequently represented in ethanol extracts from VN: negundoside, agnuside, vitegnoside, 7,8 dimethyl herbacetin 3-rhamnoside, 5,3'-dihydroxy-7,8,4' -trimethoxy flavanone, 5-hydroxy$3,6,7,3^{\prime}, 4^{\prime}$-pentamethoxy flavone, 5,7 dihydroxy- 6,4' dimethoxy flavonone, and 5 hydroxy-7,4' dimethoxy flavone, and among these, negundoside is the most active phenol acting as an antioxidant. It can protect against $\mathrm{CCl}_{4}$-induced toxicity and oxidative stress. The mechanism of protection involves decreased production of ROS and lipid peroxidation. The agnuside, vitegnoside and flavonoids present in the plants are also natural antioxidants [12,13].

VN extract showed significant levels of \% inhibition of $\mathrm{DPPH}^{\cdot}(79.43 \pm 1.3)$ compared to the standard antioxidants (BHT, gallic acid and ascorbic acid) which were used as positive control (Table 3). As shown in this table, $\mathrm{VN}$ extract was significantly $(\mathrm{p}<0.05)$ lower than BHT, galic acid and ascorbic acid at low concentrations, 3.125 and $6.25 \mu \mathrm{g} / \mathrm{ml}$ giving lowest inhibition at $2.35 \%$ and $2.58 \%$, respectively. Interestingly, this inhibition was significantly increased by the increasing the concentration from 12.3 to 25 to $50 \mu \mathrm{g} / \mathrm{ml}$ to give $79.43 \%$ with $\mathrm{IC}_{50}$ $13.31 \pm 0.18 \mu \mathrm{g} / \mathrm{L}$ (Table 3). This inhibition is too closed to $\mathrm{BHT} 82.53 \%$ with $\mathrm{IC}_{50} 13.8 \pm 0.14 \mu \mathrm{g} / \mathrm{L}$ and gallic acid $89.51 \%$ with $\mathrm{IC}_{50} 3.1 \pm 0.08 \mu \mathrm{g} / \mathrm{L}$. This clearly indicates that the $\mathrm{VN}$ extract has good radical scavenging activity compared to the pure compounds. Presumably, significantly greater inhibition of DPPH could be attributed to the presence of multi-hydroxyl groups, which is the active center of anti-oxidation like7, 8 dimethyl herbacetin 3 -rhamnoside and vitegnoside which showed radical scavenging activity $97.3 \%$ and $95.6 \%$ respectively (Table 2 ). Although we do not have an exact explanation for the greater increase of $\mathrm{VN}$ free radical scavenging activity, we could provide some logical arguments. Our published data [13] showed that VN is rich in phenolic compounds and

Table 2 Part of PASS for VN chemical compounds

\begin{tabular}{|c|c|c|c|c|c|c|c|c|c|c|c|c|}
\hline \multirow{3}{*}{ Compound } & \multicolumn{12}{|c|}{ Biological activity } \\
\hline & \multicolumn{2}{|c|}{ Lipid peroxidation inhibitor } & \multicolumn{2}{|c|}{ Antioxidant } & \multicolumn{2}{|c|}{ Free radical scavengers } & \multicolumn{2}{|c|}{ Hepatoprotectant } & \multicolumn{2}{|c|}{ Caspase-3 stimulant } & \multicolumn{2}{|c|}{ Antiproliferative } \\
\hline & $\mathrm{Pa}$ & $\mathrm{Pi}$ & $\mathrm{Pa}$ & $\mathrm{Pi}$ & $\mathrm{Pa}$ & $P$ & $\mathrm{~Pa}$ & $\mathrm{Pi}$ & $\mathrm{Pa}$ & $\mathrm{Pi}$ & $\mathrm{Pa}$ & $\mathrm{Pi}$ \\
\hline 1 & 0.813 & 0.003 & 0.699 & 0.004 & 0.786 & 0.003 & 0.717 & 0.007 & 0.741 & 0.009 & 0.737 & 0.012 \\
\hline 2 & 0.765 & 0.004 & 0.671 & 0.004 & 0.765 & 0.003 & 0.744 & 0.006 & 0.706 & 0.011 & 0.754 & 0.011 \\
\hline 3 & 0.798 & 0.004 & 0.749 & 0,004 & 0.849 & 0.002 & 0.741 & 0.006 & 0.778 & 0.007 & 0.886 & 0.005 \\
\hline 4 & 0.711 & 0.005 & 0.644 & 0.004 & 0.751 & 0.003 & 0.658 & 0.009 & 0.734 & 0.009 & 0.855 & 0.005 \\
\hline 5 & 0.952 & 0.002 & 0.874 & 0.003 & 0.973 & 0.001 & 0.912 & 0.002 & 0.812 & 0.005 & 0.817 & 0.007 \\
\hline 6 & 0.304 & 0.062 & 0.788 & 0.003 & 0.518 & 0.009 & 0.983 & 0.001 & 0.679 & 0.012 & 0.445 & 0.005 \\
\hline 7 & 0.415 & 0.031 & 0.598 & 0.005 & 0.698 & 0.004 & 0.986 & 0.001 & 0.611 & 0.006 & 0.554 & 0.014 \\
\hline 8 & 0.920 & 0.002 & 0.798 & 0.003 & 0.956 & 0.001 & 0.924 & 0.002 & 0.749 & 0.008 & 0.715 & 0.013 \\
\hline
\end{tabular}

Pa-probability "to be active"; $\mathrm{Pi}$ - probability "to be inactive".

(1) 5-hydroxy-7,4'dimethoxy flavones, (2) 5-hydroxy-3,6,7,3',4'-Pentamethoxy flavones, (3) 5, 3' dihydroxy-7, 8,4'-trimethoxy flavanone, (4) 5,7-dihydroxy-6,4' dimethoxy flavanone, (5) 7,8-dimethyl herbacetin 3-rhamnoside, (6) Agnuside, (7) Negundoside, (8) Vitegnoside. 


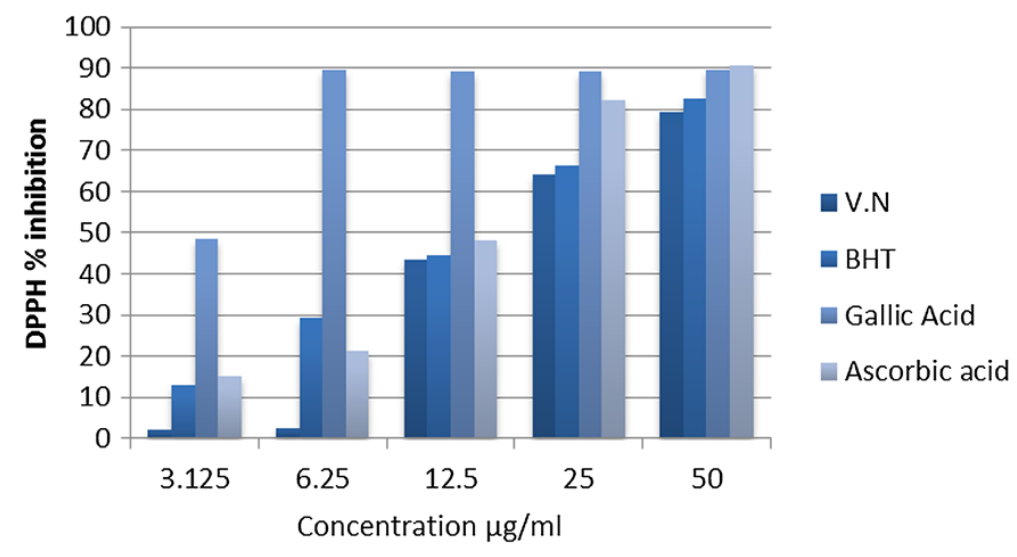

Figure 1 The percentage of scavenging activity of ethanolic extract of VN against DPPH.

provides a wide range of antioxidant properties which seems to be directly related to the hydroxyl groups attached to aromatic rings. This broad spectrum of antioxidant formula provides the best possible protection against the free radicals. This attributed to bond dissociation energy (BDE) of each hydroxyl group attached to the benzene ring. It is the energy needed to break one mole of the bond to give separated atoms. BDE plays a central role in determining antioxidant efficacy, and is one of the most important physical parameters used for evaluating antioxidant activity in chemical compounds that are used as inhibitors of free radical reactions [28]. In general, compounds having lower BDEs have been reported to have better antioxidant properties. Hence, $\mathrm{VN}$ has a wide variety of hydroxyl groups and therefore, exerts a wide variety of BDEs, forming a synergistic system between antioxidant and co-antioxidant by regeneration of antioxidants through the co-antioxidant. For instance, vitamin $\mathrm{E}(\alpha-\mathrm{TOH})$ and polyphenols can be involved in the synergistic antioxidant system. $\alpha-\mathrm{TOH}$ is consumed from the beginning of the oxidation reaction forming $\alpha$ - $\mathrm{TO}^{*}$ radical which completely preserved until all co-antioxidant ( $\mathrm{CoAH})$ has been consumed (Figure 3). Due to this peculiar behavior, polyphenolic species are ideal co-antioxidants to be used together with a small amount of vitamin $\mathrm{E}$ $[29,30]$.

The FRAP assay measures the ferric $\left[\mathrm{Fe}^{3+}\right.$-TPTZ]-toferrous $\left[\mathrm{Fe}^{2+}-\mathrm{TPTZ}\right]$ iron reduction in the presence of antioxidants. FRAP assay treats the antioxidants in the sample as a reductant in a redox-linked colorimetric reaction [31]. The trend for ferric ion reducing activity of $\mathrm{VN}$ against BHT, gallic acid and ascorbic acid are shown in Figure 2. VN exhibited the strongest free radical scavenging power compared with two commercial antioxidants, BHT and ascorbic acid. This seems to suggest that VN extract can donate electron easily. This activity is believed to be mainly due to their redox properties. Hence VN extract should be able to donate electrons to free radicals stable in the actual biological and food system.

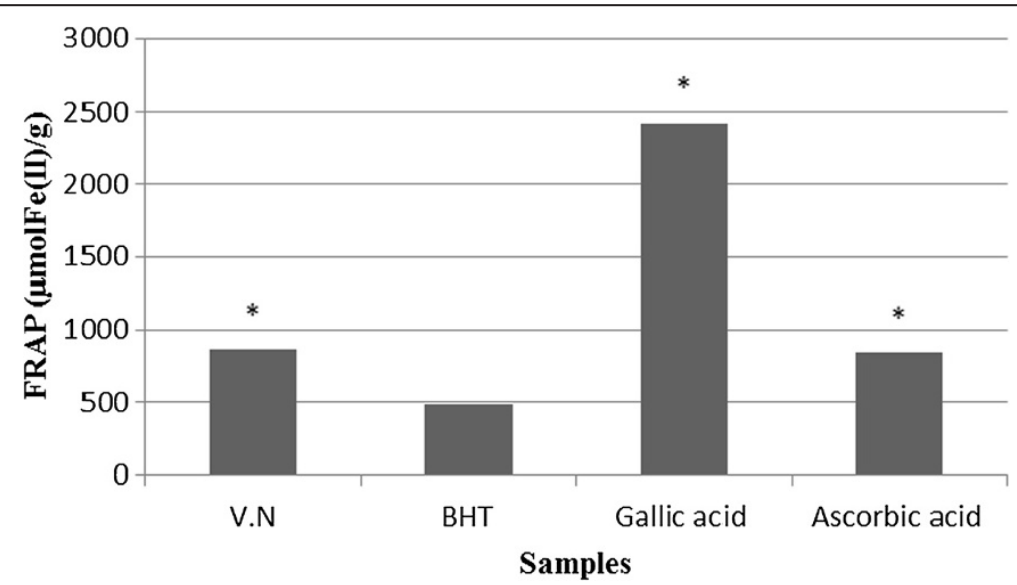

Figure 2 Ferric reducing antioxidant property (FRAP) of the leave extract of VN. Values are presented as means $\pm S E M,{ }^{*} P<0.05$ versus $\mathrm{BHT}$. 
Table $3 \mathrm{IC}_{50}$ value and percentage inhibition of the DPPH radical scavenging assay

\begin{tabular}{ccccc}
\hline $\boldsymbol{\mu g} / \mathbf{m l}$ & \multicolumn{4}{c}{ Max. inhibition\% \pm SEM ${ }^{\text {a }}$} \\
\cline { 2 - 5 } & $\mathbf{V N}$ & $\mathbf{B H T}$ & Gallic acid & Ascorbic acid \\
\hline $\mathbf{3 . 1 2 5}$ & $2.35 \pm 0.07$ & $13.05 \pm 0.07$ & $48.4 \pm 0.01$ & $15.1 \pm 0.14$ \\
$\mathbf{6 . 2 5}$ & $2.58 \pm 0.4$ & $29.15 \pm 0.21$ & $89.3 \pm 0.51$ & $21.24 \pm 0.86$ \\
$\mathbf{1 2 . 3}$ & 43.50 .47 & $44.5 \pm 0.07$ & $89.1 \pm 1.27$ & $48.06 \pm 1.18$ \\
$\mathbf{2 5}$ & $64.2 \pm 0.94$ & $66.32 \pm 0.96$ & $89.17 \pm 1.65$ & $82.09 \pm 1.09$ \\
$\mathbf{5 0}$ & $79.43 \pm 1.3$ & $82.53 \pm 1.7$ & $89.51 \pm 1.14$ & $90.65 \pm 1.34$ \\
IC50 $^{\text {b }}$ value $\boldsymbol{\mu g} / \mathbf{l} \pm$ S.E.M & $13.31 \pm 0.18$ & $13.8 \pm 0.14$ & $3.1 \pm 0.08$ & $12.9 \pm 0.12$ \\
\hline
\end{tabular}

${ }^{a}$ SEM: standard error of the mean. ${ }^{\mathrm{b}} \mathrm{I} \mathrm{C}_{50}$ : $50 \%$ effective concentration. $\mathrm{IC} \mathrm{C}_{50}$ is determined by using Masterplex 2010 software (5Parameters logistics).

The ethanolic extract of VN was found to be an effective scavenger of DPPH and FRAP with a good reducing power activity. The high antioxidant activity of $\mathrm{VN}$ enhanced the potential interest in this plant for improving the efficacy of different products as nutraceutical and pharmacological agents.

\section{In vitro antioxidant of VN for WRL68 cell lines}

The oxidative stress was induced by exposing cells to $1000 \mu \mathrm{M} \mathrm{H}_{2} \mathrm{O}_{2}$ for 2 hours while the protective effect of the plant reduce the oxidative stress. Cells were first pre-incubated with $\mathrm{VN}$ for 2 hours and then treated with $1000 \mu \mathrm{M} \mathrm{H}_{2} \mathrm{O}_{2}$. It is obvious that $\mathrm{H}_{2} \mathrm{O}_{2}$ lead to the production of reactive oxygen species (ROS), which in consequence reduced the antioxidant enzymes such as SOD and GPX. However, pre-treatment with plant extract decreased the free radical formation; therefore the antioxidant enzymes level became higher. Our results revealed that $\mathrm{H}_{2} \mathrm{O}_{2}$-exposed cells caused a statistically significant decrease $(\mathrm{p}<0.05)$ in GPX activity, whereas those exposed to VN showed significant increase in GPX activity. On the other hand, lipid peroxidation value, measured as MDA production, was significantly increased in $\mathrm{H}_{2} \mathrm{O}_{2}$ - induced oxidative stress group compared to untreated cells. Whereas in cells pre-incubated with VN extract, there was significant reduction in MDA level due to prevention of lipid peroxidation (Table 4). This is probably due to the presence of 7,8 dimethyl herbacetin 3-rhamnoside and vitegnoside which showed the highest lipid peroxidase inhibitor activity in PASS result (Table 2).

The role of oxidative stress and tissue damage in diseases, such as atherosclerosis, heart failure, neurodegenerative disorders, aging diabetes mellitus, hypertension and other several diseases are gaining a lot of recognition [32]. Reactive oxygen species (ROS) are prospective carcinogenic substances because of the generating free radicals including hydroxyl, superoxide, peroxyl, hydroperoxyl, and alkoxyl radicals, which participate in tumor promotion, mutagenesis and progression. If there is no effective regulation, the excess ROS will damage proteins, lipids or DNA and in turn inhibition of the normal function through the modulation of gene expression, cell cycle, cell metabolism, cell adhesion and cell death [33].

Glutathione is the major endogenous antioxidant scavenger that protects cells from oxidative stress through its ability to bind to and reduce ROS [34]. Thus, preserving the glutathione-mediated antioxidant defense is critical for cell survival. Glutathione is formed by $\gamma$-glutamate cysteine ligase $(\gamma-\mathrm{GCL})$ and glutathione synthetase [35]. The ethanol extract of $\mathrm{VN}$ increased the GPX and SOD activity, which indicates that this extract can effectively scavenge $\mathrm{H}_{2} \mathrm{O}_{2}$. The effects of the ethanol 
Table 4 Effects of $\mathrm{H}_{2} \mathrm{O}_{2}$, VN extract on the antioxidant enzymes and MDA level on $\mathrm{H}_{2} \mathrm{O}_{2}-$ induced WRL-68 cell line

\begin{tabular}{cccc}
\hline Group & SOD (U/mg protein ) & GPX (nmol/ mg protein ) & MDA (nmol/ g protein ) \\
\hline Normal Control & $10.61 \pm 0.010$ & $27.14 \pm 0.30$ & $17.00 \pm 1.019$ \\
$\mathbf{H}_{\mathbf{2}} \mathbf{O}_{\mathbf{2}}$ & $10.00 \pm 0.065$ & $10.98 \pm 0.18^{\mathrm{a}}$ & $46.94 \pm 1.730^{\mathrm{a}}$ \\
VN extract & $10.37 \pm 0.150$ & $22.05 \pm 0.19^{\mathrm{b}}$ & $23.17 \pm 2.165^{\mathrm{b}}$ \\
\hline
\end{tabular}

Values are presented as means \pm S.E.M, ${ }^{\text {a }} P<0.05$ versus normal control group, ${ }^{\text {b }} P<0.05$ versus $\mathrm{H}_{2} \mathrm{O}_{2}$ group.

extract of $\mathrm{VN}$ on cell viability might involve dual actions: the direct action of oxygen radical scavenging, as shown by the DPPH radical scavenging by ethanol extract (Figure 1) and the indirect action via the induction of the antioxidant enzymes of SOD and GPX (Table 4). Furthermore, the level of lipid peroxidation was significantly higher in the cells exposed to $\mathrm{H}_{2} \mathrm{O}_{2}$, while the treatment with $\mathrm{VN}$ extract apparently attenuated the MDA level. This might reflect an idiosyncrasy of the in vitro system used in this study.

\section{Cytotoxic effect of VN extract on HepG2 and WRL 68 cell lines}

Cytotoxicity of VN crud extract on HepG2 and WRL68 cells was assessed using MTT assay. Responses of HepG2 cells toward increasing concentrations of VN extract were exponential. HepG2 cells experienced a significant increase in inhibition at low concentrations of VN extract, with an eventual decline at the highest concentrations tested and with the increasing in the incubation period. The estimated $\mathrm{IC}_{50}$ values of $\mathrm{VN}$ extract were $66.46 \mu \mathrm{g} / \mathrm{ml}, 57.36 \mu \mathrm{g} / \mathrm{ml}$ and $65.12 \mu \mathrm{g} / \mathrm{ml}$ at 24 hours, 48 hours and 72 hours incubation respectively (Table 5). This means that increasing the concentration used combined with a longer period of incubation with VN extract has an impact on increasing the ability of inhibition of proliferation. This is indicated by the declining number of living cells with increasing concentrations and incubation time of HepG2 cells (Figure 4).

The cytotoxicity or anticancer activity of the crude extract expressed as the inhibitory of concentration $\left(\mathrm{IC}_{50}\right)$. The sensitivity of HepG2 cells to VN is characterized by

Table 5 Comparison of IC 50 values for HepG2 and WRL 68 cells obtained from MTT assay following exposure to VN extract for 24,48 and 72 hours

\begin{tabular}{lccc}
\hline Cell line & Extract & Duration(Hour) & $\mathbf{I C}_{\mathbf{5 0}} \mathbf{\mu g} / \mathbf{m} \mathbf{l}$ \\
\hline WRL 68 & VN & 24 & $>100^{a}$ \\
& 48 & $>100^{a}$ \\
& 72 & $>100^{a}$ \\
Hep G2 & VN & 24 & $66.46 \pm 2.8$ \\
& & 48 & $57.36 \pm 1.3$ \\
& 72 & $65.12 \pm 1.8$ \\
\hline
\end{tabular}

The $I C_{50}$ value is defined as the concentration of sample necessary to inhibit $50 \%$ of the cells. ${ }^{a}$ Value not reach $50 \%$ inhibition. $I C_{50}$ is determined by using Masterplex 2010 software (5Parameters logistics).
$\mathrm{IC}_{50}$. The lower the $\mathrm{IC}_{50}$ value indicated the higher anticancer effect of the sample. These results indicate that elevated anticancer effects strengthened with dose time of exposure (Table 5).

(Figure 5) showed that (WRL68) cells treated with $200 \mu \mathrm{g} / \mathrm{ml}$ of $\mathrm{VN}$ ethanolic extract still retained $>50 \% \mathrm{vi}$ able cells $59.86 \%$ viability. Hence, $\mathrm{VN}$ ethanolic extract predetermination by MTT assay induced cytotoxicity activity in the (HepG2), but not in (WRL68) cells.

Until now, no ideal cytotoxicity test has been developed; hence, in this study, we have screened this type of plant which is native to South Eastern Asian countries for treating a variety of ailments, including cancer by using two-cell lines, WRL68 and HepG2 cells. The micro-culture tetrazolium salt (MTT) assay was used in this study to measure the amount of cell viability. This method is based on the quantification of purplecoloured formazan, which was formed by the reduction of MTT [3-(4, 5-dimethylthiazole-2-yl)-2,5-diphenyl. The potential antiproliferative effect of ethanolic crude extract of $\mathrm{VN}$ was investigated, determining their effect on the viability of (HepG2) and (WRL 68). The reduction of MTT is proportional to the number of active mitochondria in the live cells. The results indicated that VN extract caused significant inhibition of HepG2 cells in a dose and time-dependent manner. Generally, it was found that $\mathrm{VN}$ extract at $\mathrm{IC}_{50} 57.36 \mu \mathrm{g} / \mathrm{ml}$ was cytotoxic for HepG2 cell lines after 48 hours of exposure, meanwhile, there was no $\mathrm{IC}_{50}$ value of $\mathrm{VN}$ extract against WRL 68 cell lines in all concentrations and incubation periods as shown in Table 5.

\section{Morphological observation by inverted microscope}

Observation through a light microscope of the VN ethanolic extract-treated HepG2 cell line after 48 hours of exposure showed typical morphological features of apoptosis. The characterization of morphological changes observed showed reduction in cell volume, cell shrinkage, reduction in chromatin condensation and formation of cytoplasmic blebs as shown in Figure 6.

\section{Morphological observation by acridine orange and ethidium bromide (AO/EB) staining}

Induction of apoptotic cell death among HepG2 cells was confirmed by a morphological observation of the cells after Acridine Orange/Ethidium Bromide (AO/EB) 


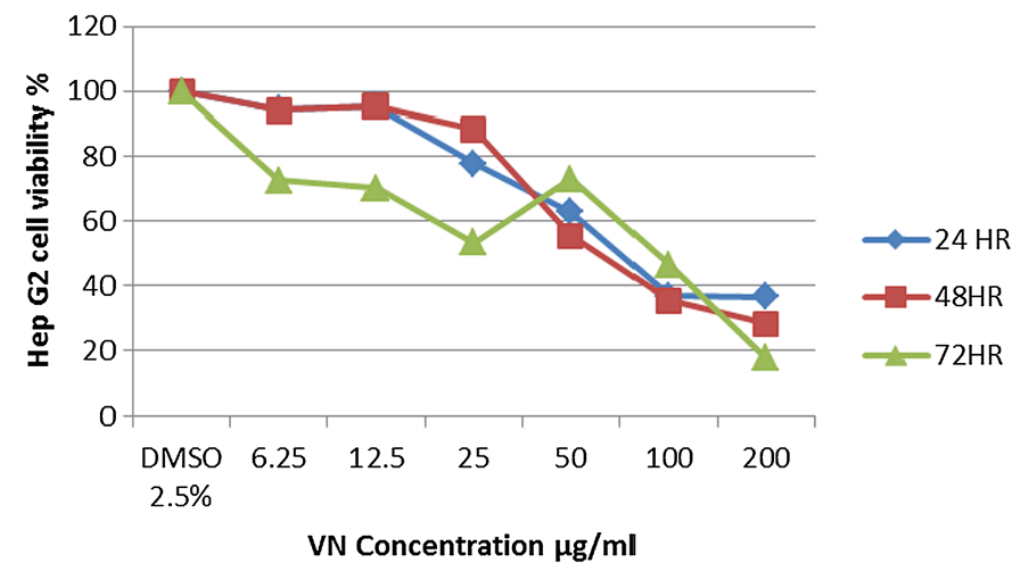

Figure 4 Effect of VN treatment on HepG2 cell lines viability.

staining assessed by fluorescence microscopy. As shown in Figure 7, the cells treated with VN showed a marked decrease in the number of live cells compared to the untreated control.

\section{LDH Release}

LDH is an enzyme located in the cell and catalyses the interconversion of lactate to pyruvate. It is another indicator of cell viability through the evaluation of membrane integrity. The LDH activity is measured externally as it leaks from dead cells or disturbed cells and in both cases the LDH activity increases. In the present study, LDH assay was carried out to evaluate the in vitro cytotoxic effect of VN extract on WRL 68 and HepG2 cells. (Figure 8) showed that the lowest LDH release was in WRL 68 cells at $50 \mu \mathrm{g} / \mathrm{ml}$ within 24 hours incubation period and it was activated with the increase of $\mathrm{VN}$ concentration and the incubation period.
On the other hand, HepG2 cells were more sensitive to VN as compared to WRL 68 cells, LDH was released in a time and dose dependent manner.

Recent studies have shown that LDH is an accurate and more reliable marker of cytotoxicity, because damaged cells are fragmented completely during the higher concentration of $\mathrm{VN}$ extract and the path of prolonged incubation with substances [36,37]. In this report, LDH amount from HepG2 cells was released in a time and dose dependent manner as shown in Figure 8 and this indicted that VN extract is less cytotoxic on WRL 68 cell lines and the highest concentration of VN $(200 \mu \mathrm{g} / \mathrm{ml})$ showed the highest toxicity on both cell lines. Based on MTT spectrophotometric assay, VN showed high antiproliferative activities toward HepG2 cell lines in a dose and time-dependent manner Figure 4A. The sensitivity of HepG2 cells to $\mathrm{VN}$ is characterized by $\mathrm{IC}_{50}$ value. These results indicate that elevated antiproliferative effects strengthened with the dose and time of exposure.

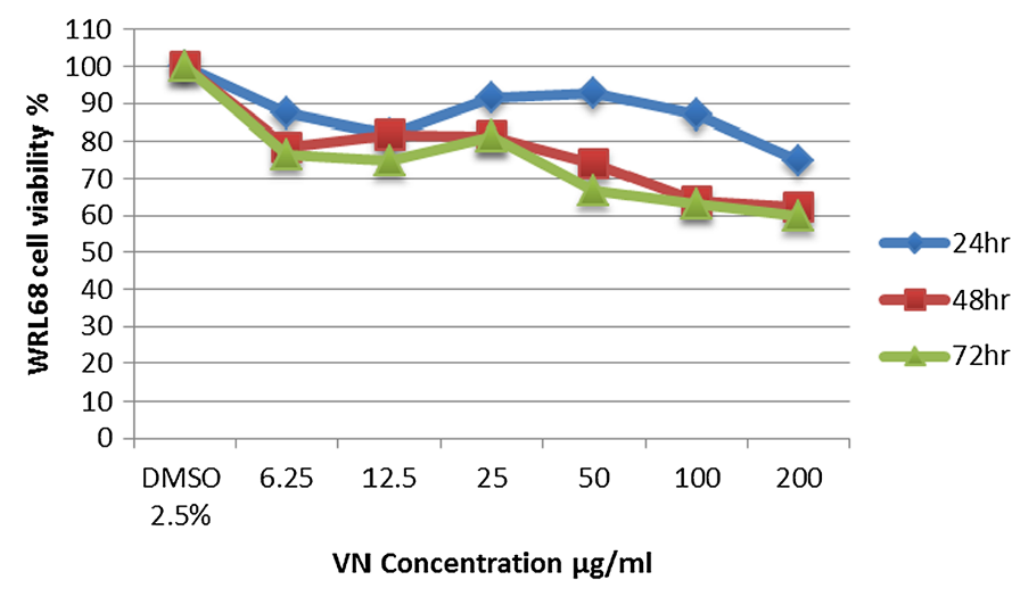

Figure 5 Effect of VN treatment on WRL68 cell lines viability. 

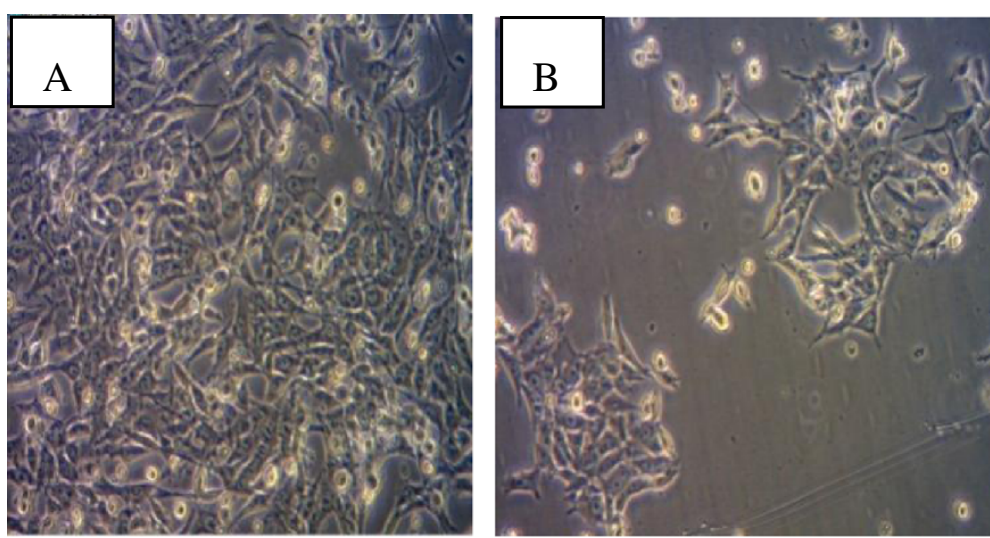

Figure 6 Photomicrographs showing the comparison of the morphology of HepG2 cells. Before and after treatment with VN extract (A) untreated cells (normal control). (B) VN treated cells, (magnification $\times 10$ ).

This was based on the average of three sets of experiments. To prove that the apoptosis has been influenced by VN ethanolic extract, HepG2 cells were examined in the presence of acridine orange and ethidium bromide staining (AO/EB staining). Acridine orange is a vital dye that will stain both live and dead cells, whereas ethidium bromide will stain only those cells that have lost their membrane integrity [38]. Cells stained green stand for viable cells, whereas reddish or orange staining illustrates late apoptotic cells. As shown in Figure 7, HepG2 cells treated with $200 \mu \mathrm{g} / \mathrm{ml}$ of ethanolic extract showed changes in cellular morphology, including chromatin condensation, membrane blebbing, and fragmented nuclei. Therefore, we can assume that stronger apoptosis is associated with high concentration of VN extract.

\section{Caspase-3 activity}

Caspase-3 activation is a vital element in the apoptotic signaling cascade. Although $\mathrm{VN}$ was not choicely cytotoxic to HepG2 cells, we were enthusiastic over check if the cytotoxicity to HepG2 cells treated with VN was mediated by apoptosis. To further elucidate the mechanism of cell death induced by $\mathrm{VN}$, a caspase- 3 colorimetric assay was conducted to establish the levels of caspase-3 activation both before and after treatment with the extract. The results of this experiment showed that treatment of HepG2 cells with VN extract strongly induces increased caspase- 3 activity as shown in Figure 9.

This high antiproliferative effect of $\mathrm{VN}$ was related to the presence of bioactive compounds such as alkaloid, flavonoids luteolin-7-glucoside, casticin, iridoid, glycosides, an essential oil and other constituents like ascorbic acid, carotene, glucononital, benzoic acid, $\beta$-sitosterol and glycoside [7]. These results are consistent with previous study which indicated that glycosides and flavones compounds possessing potent anticancer properties against MCF-7 human breast cancer cells [39].

Apoptosis represents an effective way to alleviate damaged cells through the activation of caspase and to balance the cellular proliferation [4]. Human caspase cascade is involved in chemical-induced apoptosis, caspase-3 may cleave essential cellular proteins or activate additional caspases by proteolytic cleavage [36].

To understand the molecular mechanism of $\mathrm{VN}$ induced growth inhibition, we found that there was a marked increase in the activation of caspase-3, suggesting that caspase dependent apoptotic death could be another mechanism for the beneficial effects of $\mathrm{VN}$,
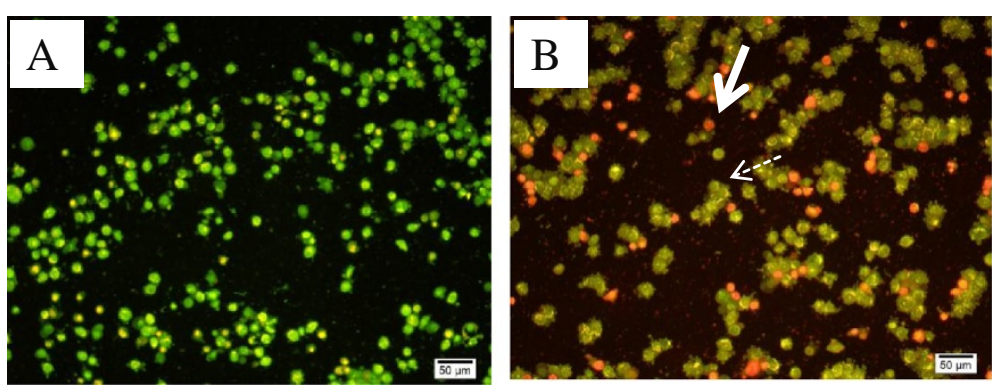

Figure 7 Effect of VN and CS on morphology of HepG2 cells. (A) Untreated controlled cells. (B) VN treated cells, full white head arrows: apoptotic cells and dashed dotted arrow indicated cell with fragmented nuclei. AO/EB staining, fluorescence microscope, Bar $=50 \mu \mathrm{m}$. 


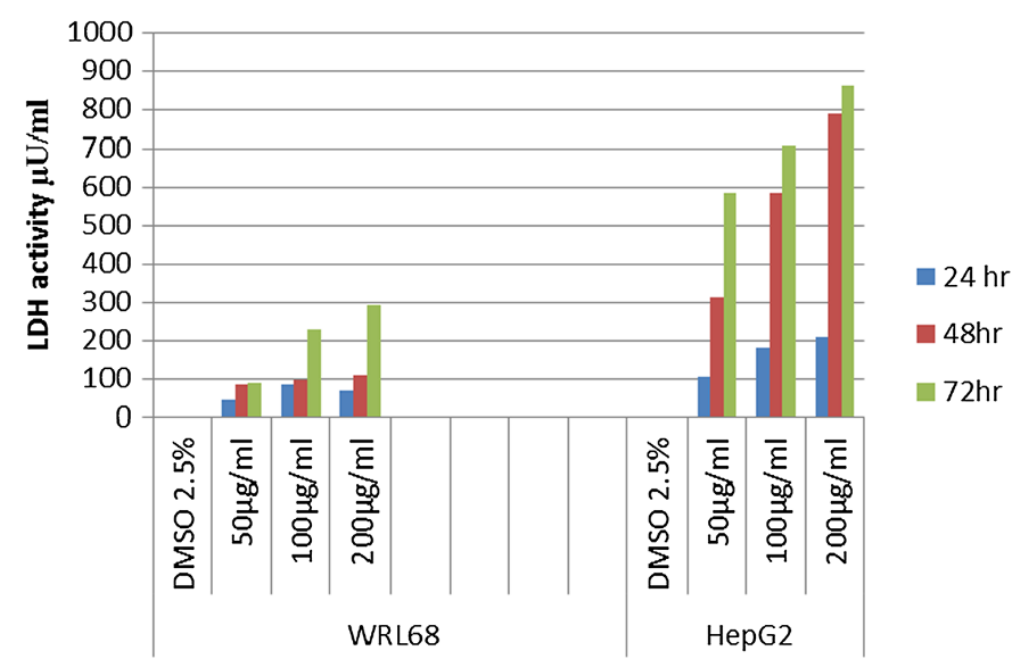

Figure 8 Effect of VN treatment in WRL68 and HepG2 cell lines on LDH release.

because it is well established that activation of caspase lead to degradation of cellular proteins, cell shrinkage, DNA fragmentation, loss of plasma membrane potential and membrane blebbing [40]. The activation of caspase3 induced chromosomal DNA break and finally the occurrence of apoptosis [41,42].

In the present investigation, $\mathrm{VN}$ extract showed the activation of caspase- 3 enzyme mediated apoptosis in HepG2 cells, and this might due to the presence of glycosides and flavones. This result is in agreement with a previous report which showed that certain products from plants can induce apoptosis in cancerous cells like OCM-1, MCF-7 and HT-29 [39].

\section{Conclusions}

PASS-prediction of VN activity has successfully applied and efficiently helped in selecting the most promising pharmaceutical leads with required properties and high accuracy. It would save unnecessary wastage of chemicals and time by avoiding random plant selection methods. It can be seen from the results of PASS that most probable activities are antioxidant, antiproliferative and hepatoprotectants. Therefore, the present approach can be very useful in plant prediction activity according to their required properties without undesirable side effects. This study strongly suggests that VN extract significantly enhanced antioxidant activity and proposed a tumour preventive action against HepG2 cell lines at a dose and time-dependent manner but with lower toxicity toward WRL68 cells. In addition, the morphological analysis using $\mathrm{AO} / \mathrm{EB}$ staining procedure revealed that the growth and proliferation inhibition is through proteolytic cleavage of caspase-3 protein and intrinsic apoptosis pathway. However, further studies are needed to

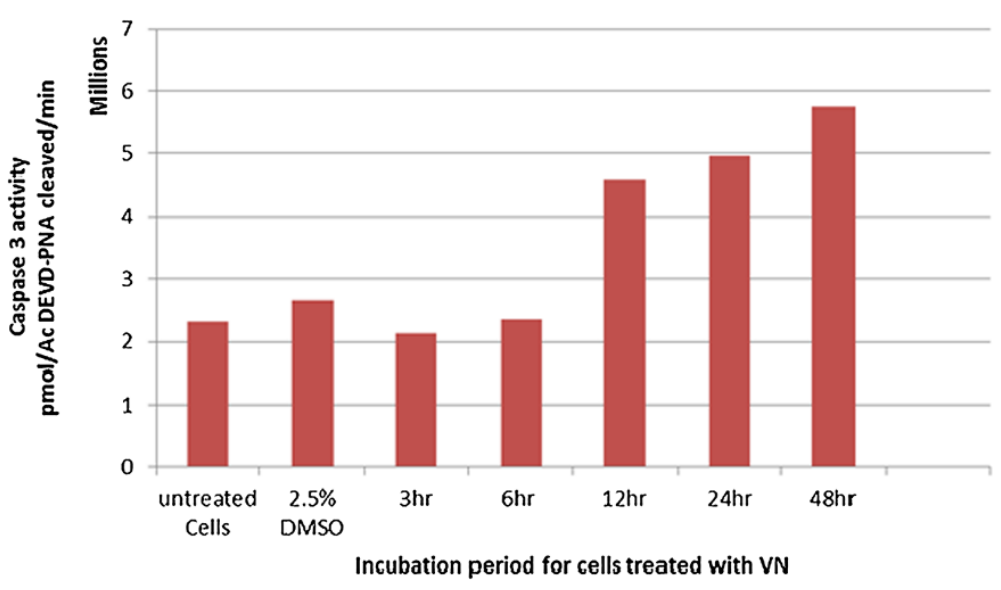

Figure 9 Caspase-3 activity of HepG2 cells treated with VN. 
determine the molecular mechanisms of the active components and to evaluate the potential in vivo anticancer activity of $\mathrm{VN}$ extract.

\section{Competing interests}

The authors declare that they have no competing interest.

\section{Authors' contributions}

Conceived and designed the experiments: FK, NMK, MAA and WAY. Performed the experiments FK, WAY. Analyzed the data: FK and WAY. Contributed reagents, materials and analysis tools: FK, NMK, MAA and WAY. Wrote the paper: FK and WAY. Editing the paper: FK, NMK, MAA and WAY. All authors read and approved the final manuscript.

\section{Acknowledgments}

The financial support from (PG087-2012B) Grant, University of Malaya, Malaysia is gratefully acknowledged.

\section{Author details \\ 'Department of Anatomy, Faculty of Medicine, University of Malaya, 50603, Kuala Lumpur, Malaysia. ${ }^{2}$ Department of Biomedical Science, Faculty of Medicine, University of Malaya, 50603, Kuala Lumpur, Malaysia. ${ }^{3}$ Nanotechnology \& Catalysis Research Centre, (NANOCAT), University of Malaya, Block 3A, Institute of Postgraduate Studies Building, 50603, Kuala Lumpur, Malaysia.}

Received: 19 August 2013 Accepted: 29 November 2013 Published: 4 December 2013

\section{References}

1. W.Y Lau L: Hepatocellular Carcinoma. Hackansack, NJ: World Scientific Pub; 2008.

2. Cheung CS-F, Chung KK-W, Lui JC-K, Lau C-P, Hon P-M, Chan JY-W, Fung K-P, Au SW-N: Leachianone $A$ as a potential anti-cancer drug by induction of apoptosis in human hepatoma HepG2 cells. Cancer letters 2007, 253(2):224-235.

3. Ganju L, Karan D, Chanda S, Srivastava K, Sawhney R, Selvamurthy W: Immunomodulatory effects of agents of plant origin. Biomedicine \& pharmacotherapy 2003, 57(7):296-300.

4. Ramos S, Alía M, Bravo L, Goya L: Comparative effects of food-derived polyphenols on the viability and apoptosis of a human hepatoma cell line (HepG2). Journal of agricultural and food chemistry 2005, 53(4):1271-1280.

5. Goodman M, Bostick RM, Kucuk O, Jones DP: Clinical trials of antioxidants as cancer prevention agents: past, present, and future. Free Radic Biol Med 2011, 51(5):1068-1084.

6. Tandon VR, Khajuria V, Kapoor B, Kour D, Gupta S: Hepatoprotective activity of Vitex negundo leaf extract against anti-tubercular drugs induced hepatotoxicity. Fitoterapia 2008, 79:533-538.

7. Gautam L, Shrestha S, Wagle P, Tamrakar B: Chemical constituents from Vitex negundo (Linn.) of nepalese origin. Scientific world 2010, 6(6):27-32

8. Singh P, Mishra G, Srivastava S, Sangeeta K, Khosa R: Phytopharmacological Review of Vitex Negundo (Sambhalu). Pharmacologyonline 2011, 2:1355-1385.

9. Manikandan R, Thiagarajan R, Beulaja S, Sivakumar MR, Meiyalagan V, Sundaram R, Arumugam M: 1,2 di-substituted idopyranose from Vitex negundo $L$. protects against streptozotocin-induced diabetes by inhibiting nuclear factor-kappa $B$ and inducible nitric oxide synthase expression. Microsc Res Tech 2011, 74(4):301-307.

10. Zheng C-J, Huang B-K, Han T, Zhang Q-Y, Zhang H, Rahman K, Qin L-P: Antinociceptive activities of the liposoluble fraction from Vitex negundo seeds. Pharm Biol 2010, 48(6):651-658.

11. Avadhoot $Y$, Rana A: Hepatoprotective effect of Vitex negundo against carbon tetrachloride-induced liver damage. Arch Pharm Res 1991, 14(1):96-98.

12. Tasduq SA, Kaiser PJ, Gupta BD, Gupta VK, Johri RK: 'Negundoside, an irridiod glycoside from leaves of Vitex negundo, protects human liver cells against calcium-mediated toxicity induced by carbon tetrachloride. World J Gastroenterol 2008, 14:3693-3709.

13. Kadir FA, Kassim NM, Abdulla MA, Yehye WA: Hepatoprotective Role of Ethanolic Extract of Vitex negundo in Thioacetamide-Induced Liver Fibrosis in Male Rats. Evidence-Based Complementary and Alternative Medicine 2013:2013. http://www.hindawi.com/journals/ecam/2013/739850/cta.

14. Sluyser M: Application of Apoptosis to Cancer Treatment. Dordrecht: Springer; 2005.
15. Parasuraman S: Prediction of activity spectra for substances. Journal of Pharmacology \& Pharmacotherapeutics 2011, 2(1):52.

16. Lagunin A, Stepanchikova A, Filimonov D, Poroikov V: PASS: prediction of activity spectra for biologically active substances. Bioinformatics 2000, 16(8):747-748.

17. Ruffa M, Ferraro G, Wagner M, Calcagno M, Campos R, Cavallaro L: Cytotoxic effect of Argentine medicinal plant extracts on human hepatocellular carcinoma cell line. Journal of ethnopharmacology 2002, 79(3):335-339.

18. Koehn FE, Carter GT: The evolving role of natural products in drug discovery. Nat Rev Drug Discov 2005, 4(3):206-220.

19. Gorinstein S, Belloso OM, Katrich E, Lojek A, Miguel MNG, Haruenkit R, Seo Park Y, Teck Jung S, Trakhtenberg S: Comparison of the contents of the main biochemical compounds and the antioxidant activity of some Spanish olive oils as determined by four different radical scavenging tests. Journal of Nutritional Biochemistry 2003, 14(3):154-159.

20. Benzie IFFS JJ: Ferric reducing/antioxidant power assay: direct measure of total antioxidant activity of biological fluids and modified version. Methods Enzymol 1999, 299:15-27.

21. Chen H, Yan X, Zhu P, Lin J: Antioxidant activity and hepatoprotective potential of agaro-oligosaccharides in vitro and in vivo. Nutr J 2006, 5(1):31.

22. Nugraheni M, Santoso U, Suparmo, Wuryastuti H: In vitro antioxidant, antiproliferative and apoptosis effect of Coleus tuberosus L. African Journal of Food Science 2011, 5(4):232-241.

23. Allen RT, Hunter WJ, Agrawal DK: Morphological and biochemical characterization and analysis of apoptosis. J Pharmacol Toxicol Methods 1997, 37(4):215-228.

24. Saad B, Dakwar S, Said O, Abu-Hijleh G, Battah FA, Kmeel A, Aziazeh H: Evaluation of medicinal plant hepatotoxicity in co-cultures of hepatocytes and monocytes. Evidence Based Complementary and Alternative Medicine 2006, 3(1):93-98.

25. George S, Bhalerao SV, Lidstone EA, Ahmad IS, Abbasi A, Cunningham BT, Watkin KL: Cytotoxicity screening of Bangladeshi medicinal plant extracts on pancreatic cancer cells. BMC Complement Altern Med 2010, 10:52.

26. Lagunin OAG AA, Filimonov DA, Gureeva TA, Dilakyan EA, Kugaevskaya EV, Elisseeva YE, Solovyeva NI, Poroikov W: Computer-Aided Selection of Potential Antihypertensive Compounds with Dual Mechanism of Action. J Med Chem 2003, 46:3326-3332.

27. A.V. P: Computer-Assisted Mechanism-ofAction Analysis of Large Databases, Including 250,000 Open NCI Database Compounds. Plant Resources 1998, 34(1):61-64.

28. Denisova TG, Denisov ET: Dissociation energies of $\mathrm{O}-\mathrm{H}$ bonds in natural antioxidants. Russ Chem Bull 2008, 57(9):1858-1866.

29. Amorati R, Ferroni F, Pedulli GF, Valgimigli L: Modeling the Co-Antioxidant Behavior of Monofunctional Phenols. Applications to Some Relevant Compounds. J Org Chem 2003, 68(25):9654-9658.

30. Yehye WA, Abdul Rahman NA, Alhadi A, Khaledi H, Ng SW, Ariffin A: Butylated Hydroxytoluene Analogs: Synthesis and Evaluation of Their Multipotent Antioxidant Activities. molecules 2012, 17(7):7645-7665.

31. Prasad KN, Chew LY, Khoo HE, Kong KW, Azlan A, Ismail A: Antioxidant capacities of peel, pulp, and seed fractions of Canarium odontophyllum Miq. fruit. BioMed Research International 2010:2010. doi: 10.1155/2010/871379.

32. Flora SJ: Role of free radicals and antioxidants in health and disease. Cell Mol Biol (Noisy-le-grand) 2007, 53(1):1-2.

33. Ha HL, Shin HJ, Feitelson MA, Yu DY: Oxidative stress and antioxidants in hepatic pathogenesis. World journal of gastroenterology: WJG 2010, 16(48):6035

34. Theiss AL, Idell RD, Srinivasan S, Klapproth JM, Jones DP, Merlin D, Sitaraman SV: Prohibitin protects against oxidative stress in intestinal epithelial cells. FASEB J 2007, 21(1):197-206.

35. Jozefczak M, Remans T, Vangronsveld J, Cuypers A: Glutathione is a key player in metal-induced oxidative stress defenses. Int J Mol Sci 2012, 13(3):3145-3175

36. Sivalokanathan S, Vijayababu MR, Balasubramanian MP: Effects of Terminalia arjuna bark extract on apoptosis of human hepatoma cell line HepG2. World J Gastroenterol 2006, 12(7):1018.

37. Hubert DJ, Dawe A, Florence NT, Gilbert KDWF, Angele TN, Buonocore D, Finzi PV, Vidari G, Bonaventure NT, Marzatico F: In vitro hepatoprotective and antioxidant activities of crude extract and isolated compounds from Ficus gnaphalocarpa. Inflammopharmacology 2011, 19(1):35-43. 
38. Raju J, Patlolla JMR, Swamy MV, Rao CV: Diosgenin, a steroid saponin of Trigonella foenum graecum (Fenugreek), inhibits azoxymethane-induced aberrant crypt foci formation in $\mathrm{F} 344$ rats and induces apoptosis in HT-29 human colon cancer cells. Cancer Epidemiol Biomarkers Prev 2004, 13(8):1392-1398.

39. Arulvasu C, Prabhu D, Manikandan R, Srinivasan P, Dinesh D, Babu G, Sellamuthu S: Induction of apoptosis by the aqueous and ethanolic leaf extract of Vitex negundo L. in MCF-7 human breast cancer cells. International Journal of Drug Discovery 2010, 2(1):1-7.

40. Timmer J, Salvesen G: Caspase substrates. Cell Death \& Differentiation 2006, 14(1):66-72

41. Salvesen GS, Dixit VM: Caspase activation: the induced-proximity model. Proc Natl Acad Sci 1999, 96(20):10964-10967.

42. Anantharam V, Kitazawa M, Wagner J, Kaul S, Kanthasamy AG: Caspase-3dependent proteolytic cleavage of protein kinase $C \delta$ is essential for oxidative stress-mediated dopaminergic cell death after exposure to methylcyclopentadienyl manganese tricarbonyl. The Journal of neuroscience 2002, 22(5):1738-1751.

doi:10.1186/1472-6882-13-343

Cite this article as: Kadir et al.: PASS-predicted Vitex negundo activity: antioxidant and antiproliferative properties on human hepatoma cellsan in vitro study. BMC Complementary and Alternative Medicine 2013 13:343.

\section{Submit your next manuscript to BioMed Central and take full advantage of:}

- Convenient online submission

- Thorough peer review

- No space constraints or color figure charges

- Immediate publication on acceptance

- Inclusion in PubMed, CAS, Scopus and Google Scholar

- Research which is freely available for redistribution 